\title{
IDEALISM AND COMMON SENSE
}

C. A. McIntosh

The question I wish to explore is this: Does idealism conflict with common sense? ${ }^{1}$ Unfortunately, the answer I give may seem like a rather banal one: It depends. What do we mean by 'idealism' and 'common sense?' I distinguish three main varieties of idealism: absolute idealism, Berkeleyan idealism, and dualistic idealism. After clarifying what is meant by common sense, I consider whether our three idealisms run afoul of it. The first does, but the latter two don't. I conclude that while Moore's famous common sense critique is sound against external world skepticism, against Berkeleyan idealism and dualist idealism it is unavailing.

\section{Idealisms}

There are at least as many different versions of idealism as there are philosophers who have professed to be such, but the family of idealisms I consider here all have in common the proposition that nothing exists without mentality, either because there is nothing that is not mental, or because non-mental reality depends in some way on the mental. By 'mental' I just mean intrinsically minded or mind-like. Ideas, consciousness, experience, etc. are all mental, or characteristic of mentality. There are still important versions of idealism to distinguish within this family, which we can do by contrasting two opposing monisms and exploring the logical space between these two poles.

According to materialist monism (sometimes just called materialism), there is only one kind of thing that exists: matter, and it is in no way mental. If there is anything that seems mental, it either doesn't exist or it is actually just material and non-mental. On the opposite side is mental monism, according to which the only one kind of thing that exists is mental. If there is anything that seems like it's not mental, it either doesn't exist or it is actually just mental. In between these monist views are dualisms which recognize the existence of both mental and non-mental realities. There are many ways to be a dualist, but I take it that the only way to be an idealist dualist is to maintain that mental reality is, in some way, more ontologically privileged than non-mental reality. Perhaps the mental 'gives rise to' the nonmental, or the non-mental otherwise asymmetrically depends on the mental. But a dualism which maintains that mental and non-mental reality are intermingled or on par with each other is not, by virtue (or vice) of its ontological egalitarianism, idealist. ${ }^{2}$

So again, broadly speaking, idealism is the view that there is nothing that is not mental, or that, if there is, it ultimately depends on mentality. There are, to be sure, distinguishable idealisms within the monist and dualist varieties (as we shall see), but for now let us turn to common sense. ${ }^{3}$ 


\section{Common Sense}

There is also no lack of variety in what one might think counts as common sense. There is, first of all, a difference between what ordinary, non-philosophers might think of as common sense, and what philosophers categorize as such.

Maybe you've been accused, or have accused someone else, of lacking common sense, or heard the quip 'common sense isn't so common.' What does 'common sense' refer to in these broader, non-philosophical contexts? Plausibly, common sense here refers primarily to well-known pragmatic or prudential imperatives, such as 'Don't spit into the wind' or moral imperatives such as 'Treat others as you'd like to be treated' or 'Don't ask a stranger when she's due.' 'Common sense' in a broader, non-philosophical context may also simply refer to commonly held beliefs that are sensible, such as 'Men are stronger than women' or 'You can't change the past' or 'The earth is round.' Although this is much closer to what philosophers mean by 'common sense,' it's not quite there. After all, 'The earth is flat' was once a commonly held, sensible belief. Even today it is commonly believed, and sensibly so, that heavier objects fall faster that lighter ones. But these would not count as a common sense beliefs by philosophers' lights. Call common sense in these broader, non-philosophical contexts vulgar common sense.

So what, then, does common sense refer to in philosophical contexts? We could do no better than to start with a list of examples from the father of common sense philosophy himself, eighteenth century Scottish philosopher Thomas Reid:

i. The thoughts of which I am conscious are my own.

ii. That which I distinctly remember actually happened.

iii. My personal identity endures through time.

iv. Things which we distinctly perceive by our senses really do exist and are as we perceive them.

v. We have some degree of power over our actions.

vi. Our faculty of reason is generally reliable.

vii. Other people are alive and conscious the way we ourselves are.

viii. The future will be like the past in relevant respects. (Reid, 1852: pp. 380-395, paraphrased)

Such propositions, Reid says, 'are no sooner understood than they are believed,' and 'are not deduced or inferred from another' (Reid, 1852: p. 424). If Reid is the father of common sense philosophy, there should be little doubt that twentieth-century English philosopher G. E. Moore was his heir. Moore also provides a list of several examples:

i. I exist and have a body.

ii. Other people like me exist.

iii. Material objects exist.

iv. Space and time are real.

v. I (and others) know these things. (Moore, 1925: pp. 32-33, paraphrased)

There are obvious points of similarity and overlap between Reid's and Moore's examples. Where common sense philosophers differ most is in what epistemic status they afford common sense beliefs. Reid maintained that common sense beliefs are irresistibly believed, self-evident 'first principles' of the intellect that cannot be argued for or against. Moore preferred to describe them as propositions we all know, and know with certainty. The nature and justification of common sense beliefs, however, need not detain us, since we are here chiefly concerned with the question of whether they-whatever their epistemic statusconflict with idealism. 
Just as we arrived at a broad understanding of idealism, it will be useful to have a broad understanding of the philosopher's common sense in hand. In Common Sense: $A$

Contemporary Defense, Noah Lemos characterizes common sense beliefs as those deeply and widely held that are taken to be matters of common knowledge. ${ }^{5}$ But this is not quite right. After all, the belief that the earth is round is deeply and widely held and taken to be a matter of common knowledge, but not a common sense belief by Reid's and Moore's lights. As reflection on their examples shows, it is important also to emphasize that common sense beliefs are often held tacitly, being too obvious to state, and are not arrived at reflectively, by investigation, or someone else's say-so. They are beliefs we simply and naturally find ourselves with as regards 'the conduct of all mankind in the common concerns of life,' as Reid puts it (Reid, 1997: p. 21). Thus in contrast to the vulgar's common sense, what we will refer to as the philosopher's common sense, or just common sense for short, is a body of deeply and widely (albeit tacitly) held beliefs, taken to be a matter of common knowledge, formed naturally and unreflectively via one's own properly functioning faculties. ${ }^{6} \mathrm{On}$, then, to our question.

\section{Does Idealism Conflict with Common Sense?}

Even if we hold fixed the above understanding of common sense, it would be unrealistic to survey the many versions of idealism, defended by this or that particular philosopher, to see whether there is conflict between them. We must, therefore, choose representatives of the main versions of idealism as distinguished above. As I see it, there are three main versions of idealism, two monistic and one dualistic.

\section{Absolute Idealism}

Consider first a monism according to which there is just one immaterial, mental thing-a mind or consciousness or spiritual substance-and nothing else. The appearance that there are non-mental, material objects, or indeed more than one thing of any kind, be it mental or non-mental, is just that: mere appearance, and an illusory one to boot. All is One, and the One is mental. Such a view, 'absolute idealism' as it is sometimes called, has a long history both East and West, but is now most closely associated with German idealists like G. W. F. Hegel and Arthur Schopenhauer and their English counterparts like F. H. Bradley and John McTaggart.

It must be conceded even by the staunchest idealist that an idealism of this sort is flatly incompatible with common sense. Indeed, absolute idealists have been known to relish in this fact. Reflecting on when he himself embraced absolute idealism, Bertrand Russell writes:

'Hegelians had all kinds of arguments to prove this or that not 'real.' Number, space, time, matter, were all professedly convicted of being self-contradictory. Nothing was real, so we were assured, except the Absolute, which could think only of itself since there was nothing else for it to think of and which thought eternally the sort of things idealist philosophers thought in their books.' (Russel, 1959: p. 62)

Any view which pillories space, time, and matter-or anything except some one mental 'Absolute' -as contradictory or unreal must be admitted to fly in the face of common sense. Surely I and many others check the time as we travel to work, believing all the while that it is $\mathrm{I}$, and not another, who is running late getting from here to there. These sorts of beliefs are not illusory or contradictory, but are deeply and widely (albeit tacitly) held, taken to be a matter of common knowledge, formed naturally and unreflectively via my own properly functioning faculties. Insofar as you hold such common sense beliefs to have positive 
epistemic status, absolute idealism is a non-starter. Russell himself credits his about-face on absolute idealism to Moore, who 'took the lead by rebellion, and I followed with a sense of emancipation.' (quoted in: Klemke, 1969: p. 3) He continues, noting the conflict with common sense:

Bradley had argued that everything that common sense believes is mere appearance; we reverted to the opposite extreme, and thought that everything is real that common sense, uninfluenced by philosophy or theology, supposes real. With a sense of escaping from prison, we allowed ourselves to think that grass is green, that the sun and stars would exist if no one was aware of them, and also that there is a pluralistic timeless world of Platonic ideas. The world which had been thin and logical, suddenly became rich and varied and solid. (Klemke, 1969: p. 3) ${ }^{7}$

We shall set aside what may be extreme in the common sense opposite to the absolute idealism against which Russell and Moore rebelled. But such an absolute idealism not merely incidentally conflicts with a common sense on account of, say, an idiosyncratic definition of 'matter,' but explicitly repudiates common sense beliefs many times over. We might say the conflict here is overdetermined. The rejection of any one of the apparent realities of space, time, matter, and a plurality of beings is sufficient for a straightforward answer to our question. Does absolute idealism conflict with common sense? Yes.

\section{Berkeleyan Idealism}

Things aren't nearly as straightforward when it comes to the much more well-known and sophisticated idealism of George Berkeley. Berkeley's idealism is monistic in that reality consists of only one kind of thing, namely, minds and their ideas, but these make up many distinct things. As he puts it, 'A certain colour, taste, smell, figure and consistence having been observed to go together, are accounted one distinct thing, signified by the name apple. Other collections of ideas constitute a stone, a tree, a book, and the like sensible things' (Berkeley, 1949b: p. 41). And so Berkeley adamantly affirms the reality of that which marks our everyday experience, insisting that his view is in line with common sense. 'I am content,' he writes, 'to appeal to the common sense of the world for the truth of my notion' (Berkeley, 1949a: p. 234). Yet Reid and Moore, our arch defenders of common sense, set their own views in direct opposition to Berkeley's. Contemporary defenders of common sense seem no less divided on the issue. Lemos, for example, says that despite his protestations to the contrary, 'Berkeley is not a member of the common sense tradition,' (Lemos, 2004: p. 11) whereas William Lycan says Berkeleyan idealism 'is immune to Moore.' (Lycan, 2019: p. 3) So does Berkeleyan idealism conflict with common sense? The issues here are subtle, and a careful, historically nuanced adjudication between Berkeley and his critics on this score is not possible here (the best treatment of which I am aware is: Pappas, 1982). It does seem to me, however, that the matter boils down to two central issues.

The first concerns a common misconception about Berkeleyan idealism which has led many to think it flagrantly contradicts common sense. For better or worse, Berkeley famously encapsulated his view the inpithy phrase esse est percepi: to be is to be perceived. Nothing exists that is not perceived to exist by a mind. Setting aside for the moment the place of matter within Berkeley's ontology, the phrase, isolated from the broader context in which Berkeley lays out and defends his view, has been thought to lead to an absurd kind of antirealist subjectivism, where there is no objective reality independent of perceivers. And if things are nothing more than their perceivable qualities, as Berkeley argues, not only does the tree that falls in the forest when no one is around not make a sound, the tree doesn't even exist. Furthermore, if to be real is to be perceived, there is nothing common to both yours and my perceptions about which we can be mistaken. But surely these are absurdities; it is part of common sense to believe in a world full of objects common to both yours and my 
perceptions that persist apart from our perceiving them, and about which we can be mistaken. But, as I say, this is a common misconception. Berkeley's idealism is thoroughly theistic: God's mind and ideas are what constitutes the world of objects common to both yours and my perceptions that in no way depends on our perceiving them. He writes,

For though we hold indeed the objects of sense to be nothing else but ideas which cannot exist unperceived; yet we may not hence conclude they have no existence except only while they are perceived by us, since there may be some other spirit that perceives them, thought we do not. (Berkeley, 1949b: p. 61; see also: Berkeley, 1949b: p. 42)

In this way, the theistic framework of Berkeley's idealism prevents it from collapsing into an absurd anti-realist subjectivism that conflicts with common sense. ${ }^{8}$

The second outstanding issue-the status of matter in Berkeley's ontology-is more serious, for if Berkeleyan idealism entails that what we ordinarily think of as material objects do not exist, then it conflicts with common sense. Of course there are such things as trees, stones, and chairs, and any philosophical view according to which there isn't, whatever its other virtues, cannot be said to be in line with common sense. This was the basis of Samuel Johnston's infamous casual dismissal of Berkeley's idealism, reported by James Boswell:

After we came out of the church, we stood talking for some time together of Bishop Berkeley's ingenious sophistry to prove the non-existence of matter, and that every thing in the universe is merely ideal. I observed, that though we are satisfied his doctrine is not true, it is impossible to refute it. I never shall forget the alacrity with which Johnson answered, striking his foot with mighty force against a large stone, till he rebounded from it,-'I refute it thus." (quoted in: Winkler, 2005: p. 1)

We have here what we might call an attempted performative refutation of Berkeley's idealism. Similar in spirit is Moore's holding up his own two hands as proof of the existence of a material world beyond his mind. Johnson and Moore are appealing to common sense beliefs to refute their target view. Because we are remaining neutral on the epistemic status of common sense beliefs, whether such performances constitute successful refutations is not the question; the question, rather, is whether they succeed in highlighting a conflict between the views and common sense; in particular, Berkeley's idealism and his (alleged) denial of material objects, be they stones or hands.

If according to Berkeleyan idealism there are no such things as stones and hands, then yes, there is a conflict with common sense, since clearly belief in such things are deeply and widely (albeit tacitly) held, taken to be a matter of common knowledge, and are formed naturally and unreflectively via one's own properly functioning faculties. But, as already shown above, Berkeley does believe in such things, and-and this is the crucial point-they would be exactly as they seem to us if Berkeley's view is correct. Stones exist; some are large, some small; some rough, some smooth; some gray, some red; some cold, some warm. Most, I imagine, feel hard if struck. Berkeley's point is just that there is nothing "beneath" an object's sensible qualities (color, size, shape, texture, and so on) that exists independently of perceivers. And with God as the perceiver and source of reality independent of us, Berkeley's theistic idealism 'would enable the idealist to avoid conflict with common sense and to retain the advantages of realism in regard to physical objects.' (Ewing, 1934: p. 386) Since neither Berkeley nor his common sense critics deny the existence of things like stones and hands, the dispute at this point becomes largely semantic: is what Berkeley means by 'material object' - a bundle of certain sensible qualities - contrary to common sense? To ask this question, however, is to leave the realm of common sense and enter the realm of the theoretical. After all, while Berkeley's answer to this question may well be offensive to 
common sense, it is no more offensive to common sense than is Locke's 'I know not what' or the physicist's 'mostly empty space.'

Moore himself, in his defense of common sense, makes a distinction that is relevant here. Moore distinguishes between understanding the meaning of an ordinary expression, on the one hand, and 'being able to give a correct analysis of its meaning' on the other (Moore, 1925: p. 37). We all know what it means to say that a rock or hand exists, or, more generally, that there are material objects. We could scarcely communicate with one another otherwise. 'But to hold that we do not know what, in certain respects, is the analysis of what we understand by such an expression, is an entirely different thing from holding that we do not understand the expression.' (Moore, 1925: p. 37) Indeed, as Moore goes on to point out, debating what the correct analysis of an expression is seems to presuppose understanding what the expression means in an ordinary sense. Thus the defender of Berkeleyan idealism can simply insist, as Berkeley himself does, that he agrees with the ordinary meaning of 'There are material objects' - happily adducing stones and his own two hands as examplesand yet offer his own theoretical analysis of the meaning of 'material object'. Berkeley writes:

'It will be argued that thus much at least is true, to wit, that we take away all corporeal substances. To this my answer is, that if the word substance be taken in the vulgar sense, for a combination of sensible qualities, such as extension, solidity, weight, and the like; this we cannot be accused of taking away. But if it be taken in a philosophic sense, for the support of accidents or qualities without the mind: then indeed I acknowledge that we take it away, if one may be said to take away that which never had any existence, not even in the imagination.' (Berkeley, 1949b: p. 56)

Now, it happens that Berkeley thought his own analysis of 'material object' is, in fact, in line with common sense. True or not, insofar as acknowledging the existence of what we ordinarily think of as material objects is part of common sense, Berkeleyan idealism is no worse than non-idealistic views which construe them as mind-independent somethings. ${ }^{10}$

It does seem to me, however, that Berkeleyan idealists embrace material objects rather coyly, knowing full well that their analysis thereof does indeed offend the unsuspecting. But once more we must remind non-idealists that their own analysis is not invulnerable to a $t u$ quoque response here. And it is not Berkeley's philosophical analysis of 'material object' that's at issue; rather, it is whether he denies the reality of those things that ordinarily fall under that description. If he does, we must answer that Berkeleyan idealism is, indeed, in conflict with common sense. But since he does not, I cannot see that it is. ${ }^{11}$

\section{Dualistic Idealism}

Our third and final idealism to consider is a dualist variety: there are two kinds of things, mental and non-mental, but the former is in some way more ontologically privileged than the latter. In this sense, a significant portion of the world's population, perhaps even a majority, are idealists: they believe the non-mental material world owes its existence to, and stands in a relationship of radical dependence on, an immaterial mind, namely, God. Philosophers often object to classifying theism, so understood, as a kind of idealism, but I see no non-arbitrary reason for doing so. Although the question of whether this or that idealism is commonsensical is not the one we are asking, it's worth noting that some have argued that belief in God is a common sense belief in roughly the sense outlined above: a belief deeply and widely (albeit tacitly) held, taken to be a matter of common knowledge, formed naturally and unreflectively via one's own properly functioning faculties (see:

Barrett, 2004; Barrett, 2012). It would be surprising, then, to learn that at least this theistic 
version of dualistic idealism conflicts with common sense. Commitment to the existence of material, non-mental realities may even be assumed in certain Christian doctrines, such as creatio ex nihilo, the incarnation, and the resurrection (on the contrary, see the relevant essays in Farris \& Hamilton, 2016; Cowan \& Spiegel, 2017). Suffice it to say that this theistic version of dualistic idealism in no way conflicts with belief in the existence of material, nonmental realities, or any other of the propositions in Reid and Moore's lists above.

There are other idealisms which prioritize the mental over the material, such as versions of Russellian monism or panpsychism, but these are highly theoretical and refined philosophical hypotheses about the fundamental nature of reality fully consistent with beliefs about how things appear at the level of familiar, everyday objects and events. Saying that phenomenality underlies the structure and dynamics of the material world, for instance, just doesn't intersect in any interesting or substantive way with common sense beliefs, and so does not conflict with them. Dualistic idealism, then, also does not conflict with common sense.

\section{Conclusion}

I have suggested that the absolute idealism associated with Hegel and Schopenhauer and their English counterparts Bradley and McTaggart does conflict with common sense, whereas Berkeleyan idealism and dualist idealism does not. I imagine that most common sense critics of idealism, especially those standing in the tradition of Reid and Moore, will bristle at this judgment. So let me say something on their behalf.

Even if some idealism itself doesn't conflict with common sense, it could be that arguments for it rely on premises which do conflict with common sense. Thus, common sense critics of idealism still may have an avenue of attack. This was, in fact, Moore's strategy in 'A Refutation of Idealism,' although there he did not appeal to common sense. He instead aimed to refute what he took to be an essential premise in any argument for idealism (namely, Berkeley's thesis that esse is percipi) rather than idealism itself. He writes:

I do not suppose that anything I shall say has the smallest tendency to prove that reality is not spiritual [i.e., that idealism is false]. ... It is, therefore, only with Idealistic arguments that I am concerned; and if any Idealist holds that no argument is necessary to prove reality is spiritual, I shall certainly not have refuted him. (Moore, 1903: pp. 2-3)

But since our question was whether idealism itself conflicts with common sense, not whether premises in arguments for idealism conflict with common sense, Moore's critique concerns us not. You might think I have made things too easy for myself, and that I should have considered the latter question, too. Perhaps. But I suspect it would be rather easy to find or produce arguments for idealism which rely on premises which do not themselves conflict with common sense. ${ }^{12}$ And it is idealism itself, not premises in arguments for it, that is often said to offend common sense.

There is good reason, moreover, to regard as significant the conclusion that at least some versions of idealism don't conflict with common sense. Ironically, Moore's most well-known argument against idealism is not found in 'A Refutation of Idealism' at all. The argument-or argument strategy, rather-is found in his common sense response to idealism and skepticism. Where $\mathrm{P}$ is some unspecified proposition, suppose you're confronted with an argument for $Q$, some unspecified view:

If $P$, then $Q$. Premise

P. Premise 


$$
\text { Q. } \quad 1,2 M P
$$

As Moore elsewhere emphasizes, ${ }^{13}$ if you are more certain that $Q$, the view being argued for, is false than that $\mathrm{P}$ is true, the proper thing to do is respond by arguing in reverse:

$\begin{array}{ll}\text { If } P \text {, then } Q . & \text { Premise } \\ \sim Q . & \text { Premise } \\ \sim P & 1,2 M T\end{array}$

The more radical of a view $Q$ is, the stronger this argument strategy will seem to be. Moore, of course, thought that idealism and external world skepticism being radical views, can be substituted in for $Q$. He is more certain of the falsity of idealism and skepticism than the truth of any premise in an argument for them. Why? He thinks idealism and skepticism flagrantly offend common sense in that they deny us knowledge of the external world of material objects. But as I pointed out above, both Berkeleyan idealism and dualistic idealism do not deny the existence of the external world of material objects. In fact, proponents of both have insisted on their respective idealism as precisely the only way to guarantee knowledge of material objects. Thus, while I think Moore's common sense response to external world skepticism is sound, to these idealisms it is unavailing. ${ }^{14}$

\section{Bibliography}

Barrett, J. (2004) Why Would Anyone Believe in God? Lanham, Rowman \& Littlefield.

Barret, J. (2012) Born Believers. Riverside, Free Press.

Berkeley, G. (1949a) Three Dialogues Between Hylas and Philonous. In: Luce, A. A. \& Jessop, T. E. (eds.) The Works of George Berkeley, Bishop of Cloyne Vol. II. New York, Thomas Nelson and Sons, pp. 147-263.

Berkeley, G. (1949b) A Treatise Concerning the Principles of Human Knowledge. In: Luce, A. A. \& Jessop, T. E. (eds.) The Works of George Berkeley, Bishop of Cloyne Vol. II. New York, Thomas Nelson and Sons, pp. 1-145.

Cowan, S. \& Spiegel, J. (2017) Idealism and Christian Philosophy. New York, Bloomsbury.

Ewing, A. C. (1934) Idealism. A Critical Survey, London, Routledge.

Farris, J. \& Hamilton, S. (2016) Idealism and Christian Theology. New York, Bloomsbury.

Kim, J. (2007) Physicalism, or Something New Enough. Princeton, Princeton University Press.

Klemke, E. D. (1969) Did G. E. Moore Refute Idealism? In: Klemke, E. D. (ed.) Studies in the Philosophy of G. E. Moore. Chicago, Quadrangle, pp. 3-24.

Lemos, N. (2004) Common Sense. A Contemporary Defense, Cambridge, Cambridge University Press.

Lycan, W. (2019) On Evidence in Philosophy. Oxford, Oxford University Press.

Moore, G. E. (1903) A Refutation of Idealism. In: Moore, G. E. (ed.) Philosophical Studies. Paterson, NJ, Littlefield, Adams \& Co., pp. 1-30.

Moore, G. E. (1919) Some Judgments of Perception. In: Moore, G. E. (ed.) Philosophical Papers. New York, Collier Books, pp. 220-252. 
Moore, G. E. (1925) A Defense of Common Sense. In: Moore, G. E. (ed.) Philosophical Papers. New York, Collier Books, pp. 32-59.

Ney, A. (2013) Ontological Reduction and the Wave Function Ontology. In: Ney, A. \& Albert, D. Z. (eds.) The Wave Function. Essays on the Metaphysics of Quantum Mechanics, Oxford, Oxford University Press, pp. 168-183.

Pappas, G. (1982) Berkeley, Perception, and Common Sense. In: Turbayne, C. (ed.) Berkeley. Critical and Interpretive Essays, Minneapolis, University of Minnesota Press, pp. 3-21.

Reid, T. (1997) An Inquiry into the Human Mind on the Principles of Common Sense. Edited by Brookes, D. R., Edinburgh, Edinburgh University Press.

Reid, T. (1852) Essays on the Intellectual Powers of Man. Edited by Walker, J., Cambridge, John Bartlett.

Roberts, J. R. (2007) A Metaphysics for the Mob. The Philosophy of George Berkeley, Oxford, Oxford University Press.

Robinson, H. (2017) Idealism and Perception: Why Berkeleyan Idealism is Not as Counterintuitive as it Seems. In: Cowan, S. \& Spiegel, J. (eds.) Idealism and Christian Philosophy. New York, Bloomsbury, pp. 71-90.

Russell, B. (1959) My Philosophical Development. New York, Simon and Schuster. Van Inwagen, P. (1990) Material Beings. Ithaca, Cornell University Press.

Winkler, K. (2005) The Cambridge Companion to Berkeley. Cambridge, Cambridge University Press.

\footnotetext{
${ }^{1}$ Note what the question is not: Is idealism commonsensical? Something may well be compatible with common sense-that is, not conflict with any common sense beliefs - and yet not itself be a common sense belief. The question is also not: Is idealism recommended by common sense? Something may well be recommended-that is, implied, entailed, supported-by common sense beliefs, and yet not itself be a common sense belief.
}

${ }^{2}$ Likewise, dualisms on which the ontological order is switched, where, say, mental states are properties of or supervene on brain states, are sometimes said to be physicalist (see: Kim, 2007).

${ }^{3}$ I have framed my discussion of idealism in terms of the mental and non-mental rather than the immaterial and material to avoid definitional controversies discussed below.

${ }^{4}$ These imperatives can be turned into beliefs by making them normative. For example, we might translate 'Look both ways before you cross the street' to 'One ought to look both ways before crossing the street.'

${ }^{5} \mathrm{And}$, in addition, common sense beliefs are taken to have greater weight than philosophical theory or proposition incompatible with them (see: Lemos, 2004: pp. 4-5).

${ }^{6}$ Although I have distinguished the vulgar's common sense from the philosopher's common sense, not all philosophers accept the distinction as I put it forward, my characterization of philosopher's common sense, or the legitimacy of appeals to common sense in philosophy. Van Inwagen (1990: $p$. 103), for instance, writes: 'I do not think that there is any such thing as the body of doctrine that philosophers call common sense. There is common sense: Common sense tells us to taste our food before we salt it and to cut the cards. It does not tell us that there are chairs. Now, in addition to common sense there is what we might call Universal Belief: that body of propositions that has been 
accepted by every human being who has ever lived, bar a few imbeciles and madmen; which is accepted even by Spinoza and Bradley when the madness of philosophy is not upon them.' Thanks to John Keller for this reference.

${ }^{7}$ See also Russell (1959: p. 54): 'Although we [Russell and Moore] were in agreement, I think that we differed as to what most interested us in our new philosophy. I think that Moore was most concerned with the rejection of idealism, while I was most interested in the rejection of monism. The two were, however, closely related.'

${ }^{8}$ The idealism that I'm saying amounts to anti-realist subjectivism is sometimes called phenomenalism. For further defense that phenomenalism conflicts with common sense, see Ewing (1934: pp. 290-315).

${ }^{9}$ The physicist's answer, in fact, is much more offensive than even the proverbial 'mostly empty space.' This point is effectively made by Robinson (2017). For instance, according to Ney (2013), macroscopic objects like tables and cats are just peaks of high-amplitude wave function that cluster around certain regions of configuration space. Take that, Berkeley! And one ironic lesson of quantum theory, no doubt heart-warming to idealists, is that the deeper we probe the material world, the larger the role mind seems to play.

${ }^{10}$ Or nothings. Some philosophically sloppy physicists make the sensationalist claim that nothing exists, since the amount of positive energy in the universe is equal to the amount of negative energy, the total energy is zero.

${ }^{11}$ One might argue that Berkeleyan idealism does conflict with common sense on the following grounds. Rocks are hard. Ideas aren't. To say rocks are a certain collection of ideas, then, is to commit a kind of category mistake. Such an argument, however, begs the question against Berkeley, for he will say it's part of his view that ideas can be hard. Ideas have other sensible qualities, too, such as sounds and smells. If you're having trouble with this, just think of how our dreams or memories can have a phenomenality to them, such that I can, in some sense, smell a smell I remember smelling, or push up against obstacles in my dreams. That said, Berkeley warns against confounding visions of a dream, which are 'dim, irregular, and confused' with 'ideas perceived by sense, that is, real things' which are 'more vivid and clear' (see: Berkeley, 1949a: p. 235).

12 Here's one: If theism is true, idealism is true. Theism is true. Therefore, idealism is true. One significant virtue of this argument is that both Berkeleyan idealists and dualist idealists (presumably) accept it.

13 Moore (1919: pp. 227-228): ‘I think we may safely challenge any philosopher to bring forward any argument in favor either of the proposition that we do not know [some proposition of common sense], or of the proposition that it is not true, which does not at some point, rest upon some premise which is, beyond comparison, less certain than is the proposition which it is designed to attack.'

${ }^{14} \mathrm{I}$ am indebted to Benjaman Arbour for many lively and, at times, tense discussions about idealism over the years, including the day before his passing. I trust that he would be pleased with what I say here. 